\title{
THE PERCEIVED VALUE OF DESIGN FOR NEW PRODUCTS AT MICRO AND SMALL COMPANIES
}

\section{EL VALOR PERCIBIDO DEL DISEÑO PARA NUEVOS PRODUCTOS EN MICRO Y PEQUEÑAS EMPRESAS}

\author{
Edu G. Mazzini Junior ${ }^{1}$, Elpidio O. B. Nara ${ }^{\circledR}{ }^{\bowtie}$ Liane M. Kipper $^{2}$, Julia W. Reuter ${ }^{2}$, Heloisa P. Burin ${ }^{3}$ \\ ${ }^{1}$ Universidade Federal de Alagoas (UFAL), Maceió, Alagoas, Brasil \\ ${ }^{2}$ Universidade de Santa Cruz do Sul (UNISC), Santa Cruz do Sul, Rio Grande do Sul, Brasil \\ ${ }^{3}$ Universidade Federal de Santa Maria (UFSM), Santa Maria, Rio Grande do Sul, Brasil \\ elpidio@unisc.br
}

Recebido: 14 agosto 2019 / Aceito: 04 novembro 2019 / Publicado: 17 dezembro 2019

\begin{abstract}
The research aims to identify and promote improvements in the planning and development processes of new products with the insertion of the design. The study was developed in three micro and small furniture companies, which are located in the city of Santa Maria-RS. This market segment was chosen because it has changes in the execution of its productive processes and by the constant search of new products in order to meet the requirements of its customers. Based on the evaluations of the final consumers and the control of the information provided by the managers of the planning and production sectors, it was sought to qualify the products based on the design. A multiple case study was used in order to identify the main differences between visions in the generation of new products. Based on this, the quality evaluation matrix, Quality Function Deployment (QFD) was used to identify and quantify procedures that have a greater impact between the planning and execution of new tailored furniture. It was possible to detect difficulties in the insertion of the design in the Furniture Industries. It is necessary to overcome some obstacles to change the company's culture regarding the management of new products.
\end{abstract}

Keywords: Quality Function Deployment, Furniture Industries, design, New products
RESUMEN. La investigación tiene como objetivo identificar y promover mejoras en los procesos de planificación y desarrollo de nuevos productos con la inserción del diseño. El estudio se desarrolló en tres micro y pequeñas empresas de muebles, ubicadas em Santa Maria-RS. Este segmento de mercado fue elegido porque tiene cambios en la ejecución de sus procesos productivos y por la búsqueda constante de nuevos productos para cumplir con los requisitos de sus clientes. Sobre la base de las evaluaciones de los consumidores finales y el control de la información proporcionada por los gerentes de los sectores de planificación y producción, se buscó calificar los productos según el diseño. Se utilizó un estudio de caso múltiple para identificar las principales diferencias entre visiones en la generación de nuevos productos. Basado en eso, se utilizó la matriz de evaluación de calidad, Despliegue de la Función de Calidad para identificar y cuantificar los procedimientos que tienen un mayor impacto entre la planificación y la ejecución de nuevos muebles a medida. Fue posible detectar dificultades en la inserción del diseño en las industrias del mueble. Es necesario superar algunos obstáculos para cambiar la cultura de la empresa con respecto a la gestión de nuevos productos.

Palavras-chave: Despliegue de funciones de calidad, industrias de muebles, diseño, nuevos productos 


\section{REVISTA LATINO-AMERICANA DE INOVAÇÃO E \\ ENGENHARIA DE PRODUÇÃO}

\section{INTRODUCTION}

Based on the current scenario of organizations, highly globalized and competitive, it becomes indispensable to search for a differentiation and development of their products. According to Tyagi et al. (2015) the planning and product development, covers from market research to the delivery of the product to the final customer, requiring that companies adapt their needs according to the variation of their products. This becomes more relevant in industries such as furniture, which in the vast majority need to modify their procedures constantly and do not have an established structure for planning and product development.

The Brazilian furniture industry is composed predominantly by small companies, and the insertion of design professionals, contributes to the change of the situation of the small furniture companies small businesses. As Godoy et al. (2012) emphasize in a case study conducted in small companies in the municipality of Santa Maria, RS, in 2003, between 30\% and $40 \%$ of the companies participating in RedeMov (The Furniture Network) have a designer responsible for new product planning.

A tool for planning new products is the Quality Function Deployment (QFD), it is possible to check market trends and offer Innovative and desired solutions. Also, the method seeks to listen to the customer in order to perceive their needs, making the product more accepted on the market (SCALVENZI; CAUCHICK, 2016). Costa (2017), the QFD is also known to be the house of quality, because through the opinion of its customers, there is the possibility of evaluating the aspects and develop the necessary improvements.

The QFD method was of paramount importance for the development of the work as an effective tool for the identification and evaluation of the requirements involved in the study. Thus, in using this method, it was sought to contribute to the continuous improvement of the processes of production and planning of new products in small companies. This study sought to quantify the value attributed to the design of products in three micro and small companies in the furniture sector of the city of Santa Maria-RS.

\subsection{THEORETICAL FOUNDATION}

1.2.1 The micro and small companies in Brazil's furniture sector 


\section{REVISTA LATINO-AMERICANA DE INOVAÇÃO E ENGENHARIA DE PRODUÇÃO}

Brazil has approximately 16,500 furniture manufacturers, and the vast majority is considered a micro and small enterprise (MPE) owned and managed with family base, where only one person is responsible for all management and control of the company, not having a sector especially for the planning of new products. Ramos and Zilber (2015) emphasize that investing in this sector can contribute to improve the company's activities, becoming a differential in competitive markets.

Dal Piva (2007) highlights some benefits regarding the manufacturing process of custom furniture: possibility of financing for the manufacture of the product; customized production; furniture adapted to the space of the residence; product with greater durability; higher profitability per product produced. Disadvantages: excess manual operations; low availability of labor; it requires a lot of raw material, increasing the cost of the product.

\subsubsection{Essentials of Design}

The concept of product design evolved over time, and designers today are no longer concerned only with the visual aspect of a product but also with the needs of the target-public and with the relationship of the product developed with humanity and the environment.

Product design is an important influence between the evaluations received by consumers and the possible success of new products. The research around the design is realized with a wide link between various sectors, such as recycling, engineering and ergonomics (LIN et al., 2016). Therefore, design is the central factor of the innovative humanization of technologies and the crucial factor of cultural and economic interchange.

Based on the diversification of consumer choices, a new product requires thought to meet the needs of users in order to be managed for them, a designer must think a lot of the characteristics of the new product, such as your design, aesthetics, functionality, material and standardization of the new product (KO and LO, 2017). 


\section{REVISTA LATINO-AMERICANA DE INOVAÇÃO E \\ ENGENHARIA DE PRODUÇÃO}

\section{METHOD}

To conduct the procedures for this article, a multiple case study was used, given that according to Yin (2005) this procedure is an empiric form of investigating contemporary phenomenon within their real context, especially when the borders between the phenomenon and the context are not clearly evident. In this case, the study is characterized as multiple because it involves the participation of three micro and small companies, to provide a general view of these micro and small made-to-order furniture companies in relation to their newproduct planning processes.

First step: Defining the agents of the study

This step involves the formatting of the work teams that will be responsible for undertaking the study. There will be three teams divided into: clients, planning managers and production managers.

Second step: Identification of the new production conception

The purpose is to analyze the practical aspects, by conducting a multiple case study, which will consider the position of the furniture companies in relation to new product development, seeking to identify and qualify the view of the product planning managers about the procedures involved in the conception of made-to-order furniture projects.

Third step: Qualify the design of the product employed

Identification of the transfer and control of information from the design projects between the planning sector and the production sector, through the observation method. Also, evaluate the design of the product developed by the planning staff, thus seeking to identify which aspects of the projects for new furniture products have greater impacts on the processes for execution of the projects realized.

Fourth step: Qualify the design of the product developed

Based on the use of a closed questionnaire method, an attempt was made to qualify the design based on the evaluation of the final client of the product developed. This procedure seeks to address aspects of the product's design, which will be confronted with the requirements stipulated in the project briefing, during the client service step.

Fifth step: Quantify the value attributed to product design 


\section{REVISTA LATINO-AMERICANA DE INOVAÇÃO E ENGENHARIA DE PRODUÇÃO}

Quantify the result of the studies through the evaluation of quality, by using the QFD method, to identify the procedures or deviations that have greater impact between the planning and execution of the made-to-order furniture projects, thus generating actions for continuous improvement. After the finalization of this step, responses will be formulated to address the question: "how and what can be done to promote improvement in the processes for the development and execution of products in micro and small companies?"

\section{RESULTS}

\subsection{DEFINING THE RESEARCH SCENARIO}

For the sealing of the companies, five criteria were considered: performs custom mobile projects for residential use; It has up to 49 employees; It has a sector dedicated to product planning; has a professional responsible for the management of design projects; would give access to the data needed for research.

Of the 33 organizations found in the city of Santa Maria-RS, only 29 met the criteria, but only three micro and small businesses agreed to collaborate with the study and provide access to the researcher. In companies, the raw materials used are the particleboard sheets with synthetic laminated coverings, in order to reduce the costs of the product as they do not require the painting process.

\subsection{QUANTIFY THE VALUE ATTRIBUTED TO PRODUCT DESIGN}

This step sought to quantify the result of the studies, by using the QFD method. This methodological procedure uses the perceptions of the planning managers and production managers to identify compatibilities or divergences between planning and execution of the made-to-order furniture products. After finalization of this step, responses would be formulated to answer the following question: "how and what can be done to promote improvement in the process for development and execution of products in micro and small companies?"

The variables were organized in two groups that allowed the quantification of the design undertaken based on a visualization of the chain of processes dedicated to the 


\section{REVISTA LATINO-AMERICANA DE INOVAÇÃO E ENGENHARIA DE PRODUÇÃO}

conception of new furniture products. To do so, the project methodologies of Bonsiepe (1984) and Baxter (2000) were adopted, which, in combination with the results of the mapping of the processes, served as references for the elaboration of the variables that influence the methodological procedures. Table 1 demonstrate the series of procedures involved in the process of new product development based on design.

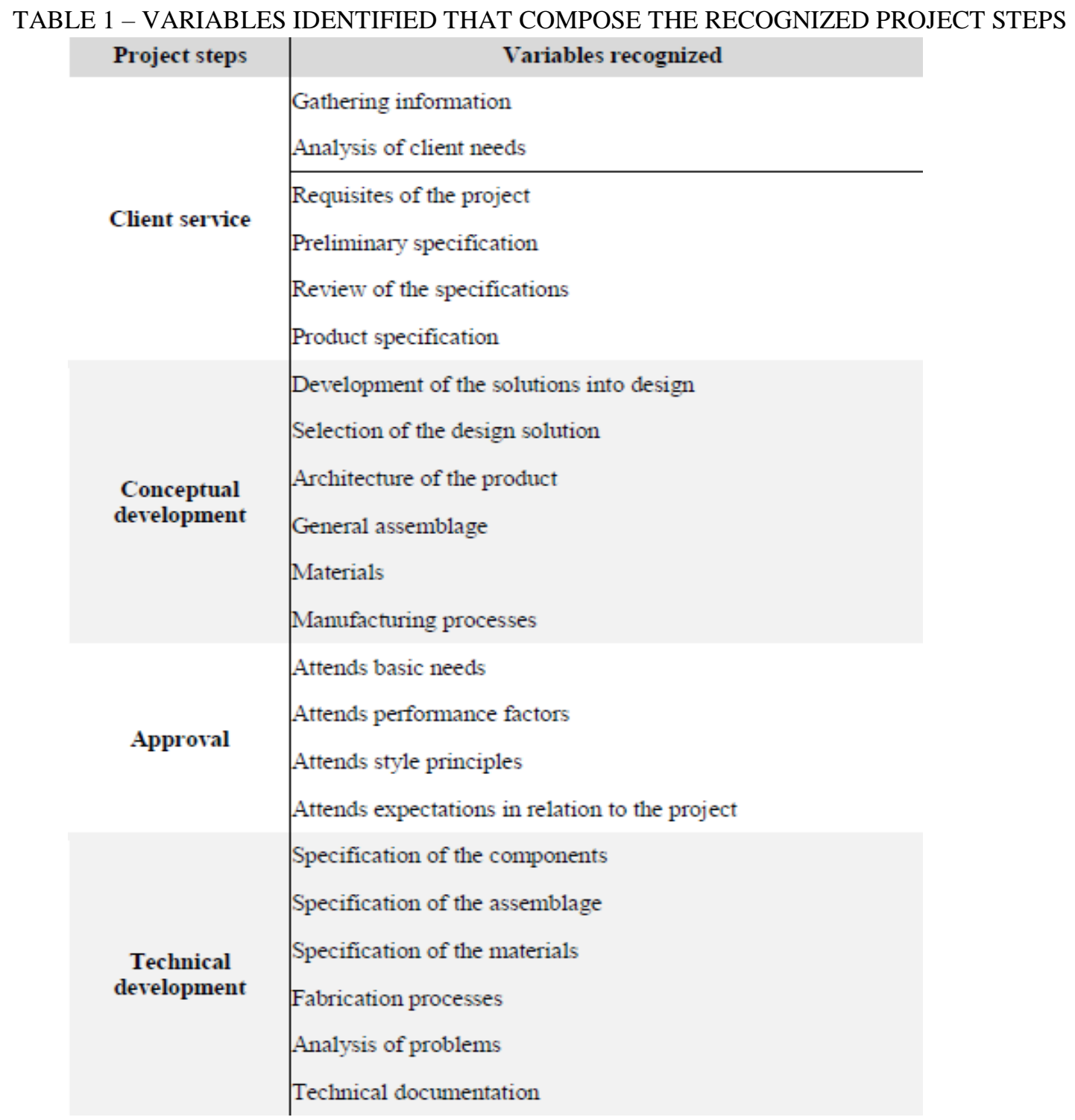

SOURCE: Authors (2018) 


\section{REVISTA LATINO-AMERICANA DE INOVAÇÃO E ENGENHARIA DE PRODUÇÃO}

After the definition of first variables group, it was necessary to develop a quantitative scale of value, with five classifications according to the performance or the effectiveness of each variable checked. For each qualification, a score from " 5 " to " 1 " is given as seen in Table 2.

TABLE 2 - SCORE OF PERFORMANCE AND OR EFFICIENCY

\begin{tabular}{c|c|c|c|c|} 
Excellent & Good & Regular & Poor & Bad \\
\hline+5 & +4 & +3 & +2 & +1 \\
\hline \multicolumn{4}{c}{ SOURCE: Authors (2018) }
\end{tabular}

Once the evaluation criteria were defined, the step for verification and quantification of the object of study was begun. The purpose is to evaluate the effectiveness of the procedures that compose the project method employed (first group of variables), based on the second group of variables. The execution of the quantitative procedure proposed, was based on the submission of the variables that compose the project method employed to evaluation by those responsible for the management of new product.

The technical development step was quantified by the production managers. Meanwhile, the approval step is characterized as the point of encounter between the areas of operation of the planning managers and the production managers, which means that the approval step is based on the definitions of the project and the documents prepared by the planning managers; while the realization of the process related to the approval is executed by the production managers.

Once the first group of variables referring to the project method employed by the companies evaluated was determined, as well as the procedure for their quantification, the second group of variables was developed, which are responsible for the characterization of the design prepared by the planning managers of the participating companies.

According to Bonsiepe (1984) and Baxter (2000), the design developed, which was materialized in a tangible product, is conditioned by the results of the development of solutions to four sets of variables, with these groups called classes of problems (Table 03). 


\section{REVISTA LATINO-AMERICANA DE INOVAÇÃO E ENGENHARIA DE PRODUÇÃO}

TABLE 3 - VARIABLES CONSIDERED FOR THE CLASSES OF PROBLEMS

\begin{tabular}{|c|c|}
\hline Class of problem & Variables considered \\
\hline \multirow{5}{*}{ Structural } & Typology of the components \\
\hline & Typology of the subsystems \\
\hline & Typology of the joints \\
\hline & Fabrication processes \\
\hline & Raw material used \\
\hline \multirow{3}{*}{ Functional } & $\begin{array}{l}\text { Characteristics of use } \\
\text { Main function }\end{array}$ \\
\hline & Secondary functions \\
\hline & Function of the components \\
\hline \multirow{3}{*}{ Ergonomics } & Ergonomics applied to the use/task \\
\hline & Anthropometrics applied to the use/task \\
\hline & Safety \\
\hline \multirow{6}{*}{ Morphology } & Formal conception \\
\hline & Chromatic finish \\
\hline & Treatment of surfaces \\
\hline & Symbolism of the product \\
\hline & Semantics of the product \\
\hline & OURCE: Authors (2018) \\
\hline
\end{tabular}

\subsection{QFD: THE VALUE ATTRIBUTED TO PRODUCT DESIGN}

This step sought to determine the value attributed to the design developed by the participating companies, by using the QFD method. The composition of the quality matrix was determined by the data taken from the evaluation of the planning and production managers of the variables that compose the project steps, which are shaped as needs of the clients. Meanwhile, the group of variables used for determining the characteristics of the design developed, denominated as classes of problems, is configured as the requirements of the project employed in the composition of this matrix.

By correlating the data in the quality matrix, it is possible to highlight the variables that format the classes of problems, which determine the characteristics of design developed, which acquire greater weight for the execution of procedures that compose the project steps (BONSIEPE, 1984 and BAXTER, 2000).

Figure 1 indicates the performance of the entire new product conception process in the search for effectiveness of the actions related to the formulation of the characteristics of each variable that composes the class of problems and that, in this way, configure the design 


\section{REVISTA LATINO-AMERICANA DE INOVAÇÃO E ENGENHARIA DE PRODUÇÃO}

developed, including the identification of needs in conjunction with the client in the client service step, the conceptual development of the new product, the approval of the definitions developed for planning management, the definitions of a technical-constructive character and the preparation for production, undertaken by the production manager in the technical development step.

\section{DISCUSSION}

It is initially observed in the results presented in figure 1, that although the companies evaluated have different performance indexes in relation to the definitions of the variables that compose the classes of problems, it is possible to identify that the points with higher quantification are similar throughout the new product conception process. Thus, the variables that determine the value of design developed by these companies receive the same emphasis during the determination of the characteristics that format the classes of the problem for each project step realized.

FIGURE 1 - GRAPH OF THE RESULTS OF THE QUALITY MATRIX FOR THE NEW PRODUCT

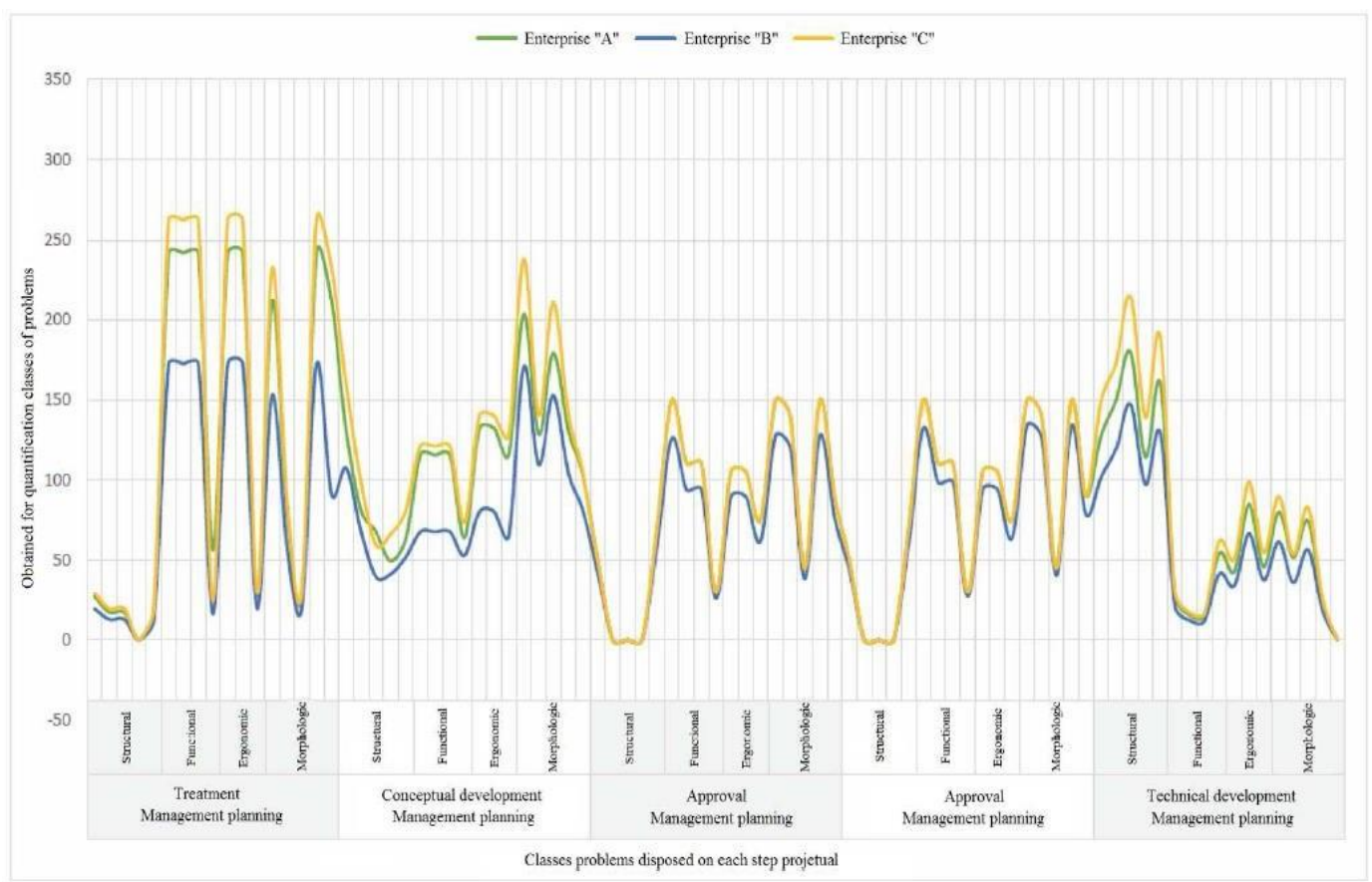

CONCEPTION PROCESS

SOURCE: Authors (2018)

For the companies "A", "B" or "C," the best results obtained in relation to the realization of the project step for client service refer to the definitions of a functional character and later, to definitions for the morphological and functional aspects. It is perceived the 


\section{REVISTA LATINO-AMERICANA DE INOVAÇÃO E ENGENHARIA DE PRODUÇÃO}

questions of a structural character have a low quantification in relation to the other classes of problems, with these variables being developed in the following project step under the responsibility of the production manager.

The conceptual development step, according to Baxter (2000), focuses on the conversion of the needs raised and interpreted in the previous project step into tangible characteristics that will format the product being developed. This step also involves defining the raw materials to be used. These definitions support the realization of the following project step and the determination of the project budget. The approval step is based on the morphological and functional definitions of the new product, which are decisive for the validation of the project by the contracting party.

Finalizing the project steps related to the method used to develop new products based on design, the technical development step stands out, which in Baxter's (2000) project methodology, refers to the determinations of the "principles of project for detailing all the components." This step is based on the specifications and determinations of the technical and constructive character of the new product.

Based on the methodologies of Bonsiepe (1984) and Baxter (2000) on the perceptions of those involved in the process, the similarity of the quantification for the variables that compose the approval step stands out. The questions raised are: how can this project method, ratified by scientific project methodologies, with similar focuses for the development of the classes of problems that configure the design developed have a quantification different from the determination of these characteristics in the companies participating in the case study? That is: how can the efforts of the agents involved in the development of the design at company "C" present higher quantification concerning the development of the variables that configure the characteristics of the new product than those of company "B"?. The response to this question is the way that the staffs are configured for the execution of these procedures.

It is thus perceived that the model found at company " $\mathrm{C}$ " are based on the interaction between the planning and production managers in the determination of the characteristics that compose the design developed. This interaction is present in the client service step, enhancing its results. While the planning managers strive to determine the needs of the project, the production managers promote the adaptation of these characteristics, qualifying the information passed to the next project step, the conceptual development of the new product. 


\section{REVISTA LATINO-AMERICANA DE INOVAÇÃO E ENGENHARIA DE PRODUÇÃO}

To resolve these doubts, we turn to the qualification of the perception of the final clients undertaken in the methodological procedure, which is called "evaluation of the results of the satisfaction questionnaire" and which is presented in a generalized manner, or in a group for the clients of companies "A", "B" and "C." In this way, Figure 2, which refers to the qualification of the classes of problems that shape the design developed only of clients of company " $\mathrm{C}$ ", shows that the results indicate a better quantification for the variables admitted than the results obtained from the perception of the clients of company "B" (Figure 3) and the clients of company "A"(Figure 4).

FIGURE 2 - QUALIFICATION OF THE CLASSES OF PROBLEMS ACCORDING TO THE PERCEPTION OF THE CLIENTS OF COMPANY “C”

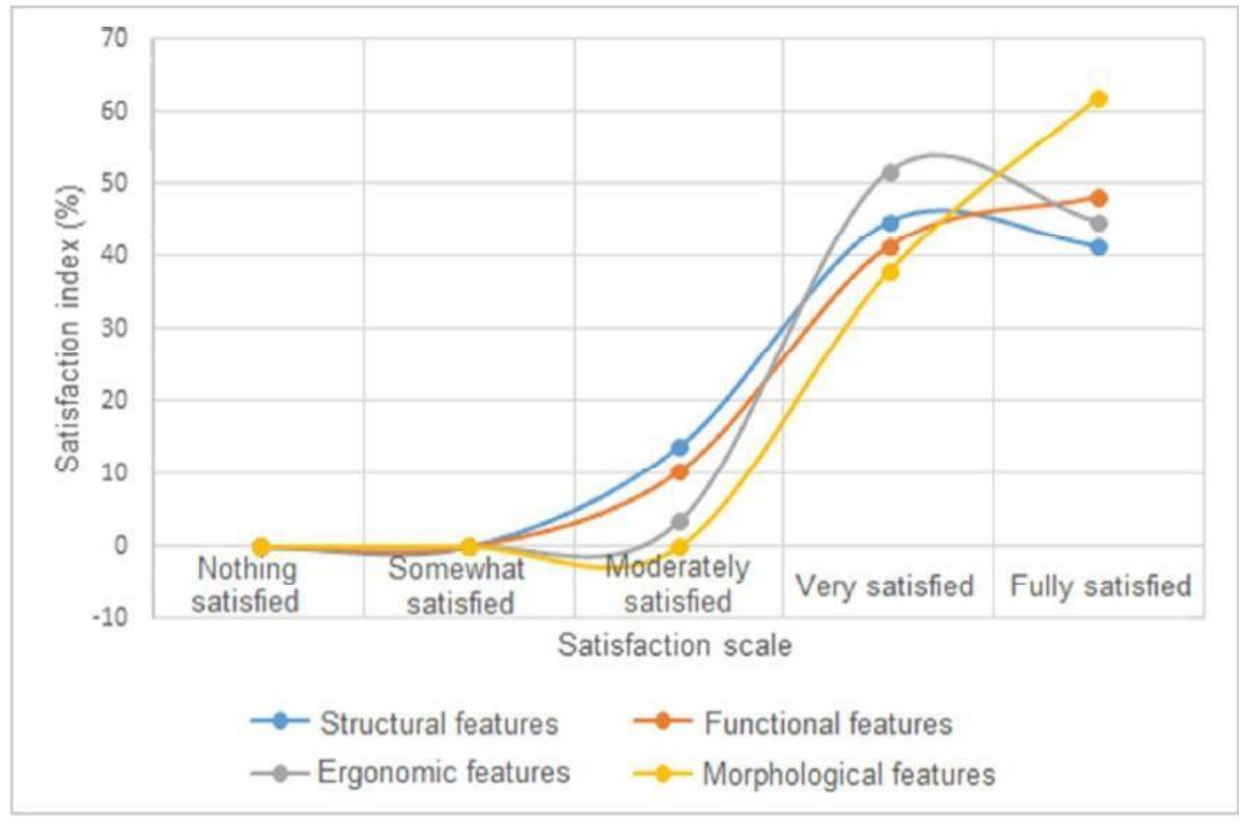

SOURCE: Authors (2018)

In the company " $\mathrm{C}$," the morphological characteristics determined that have a higher quantification stand out, although the characteristics of a functional, ergonomic, and structural character had been qualified as "totally satisfied" and "very satisfied", revealing and corroborating the vision and the work method employed by the company's planning and production managers. The results referring to the qualification of the classes of problems, based on the perception of the final clients of company "B" (Figure 03) stand out. 


\section{REVISTA LATINO-AMERICANA DE INOVAÇÃO E \\ ENGENHARIA DE PRODUÇÃO}

FIGURE 3 - CLASSES QUALIFICATION OF PROBLEMS ACCORDING TO THE PERCEPTION OF CLIENTS OF COMPANY "B"



SOURCE: Authors (2018)

Company "B" has lower quantification for the variables that configure the classes of problems evaluated, although an average classification considering the scale of value used for the determinations of structural value. Meanwhile, the definitions of morphological, functional and ergonomic character are divided between "moderately satisfied" and "very satisfied" unlike the evaluations of company "C" which had a higher score.

The results, both for the perception of the final clients (Figure 3) and the perception of the agents involved (Figure 1), are associated to the reduced interaction between the planning and production managers, which indicates that the product conception process is based on a fragmented design of characteristics. The execution of the procedures occurs in the client service step through the production management, which is responsible for identifying and interpreting the needs of the client.

This information is transferred to the planning management which concentrates solely on the conversion of the requirements stipulated into a product of a conceptual character, which is used as a reference for the approval of the project by the client. The participation of the planning management does not go beyond the conceptual development step. The responsibility for making decisions about the project is left solely with the production management. This reveals a fragmentation in the conception process, limiting the action of the agent who develops the concept for the new product, and impeding his intervention 


\section{REVISTA LATINO-AMERICANA DE INOVAÇÃO E ENGENHARIA DE PRODUÇÃO}

whenever there are doubts or restrictions in the project. This situation exacerbates the discrepancies between the project that is conceptually developed and the materialized project.

To conclude, the performance obtained based on the qualification of the classes of problems recognized for the study stands out, according to the perception of the final clients of company "A" (Figure 04). This perception ratifies the quantification obtained by the managers involved, presented in figure 1, indicating that company "A" has an intermediary performance in relation to the other companies evaluated, although closer to that of company "C", which has the best evaluation.

\section{FIGURE 4 - QUALIFICATION OF THE CLASSES OF PROBLEMS ACCORDING TO THE PERCEPTION OF THE CLIENTS OF COMPANY "A"}

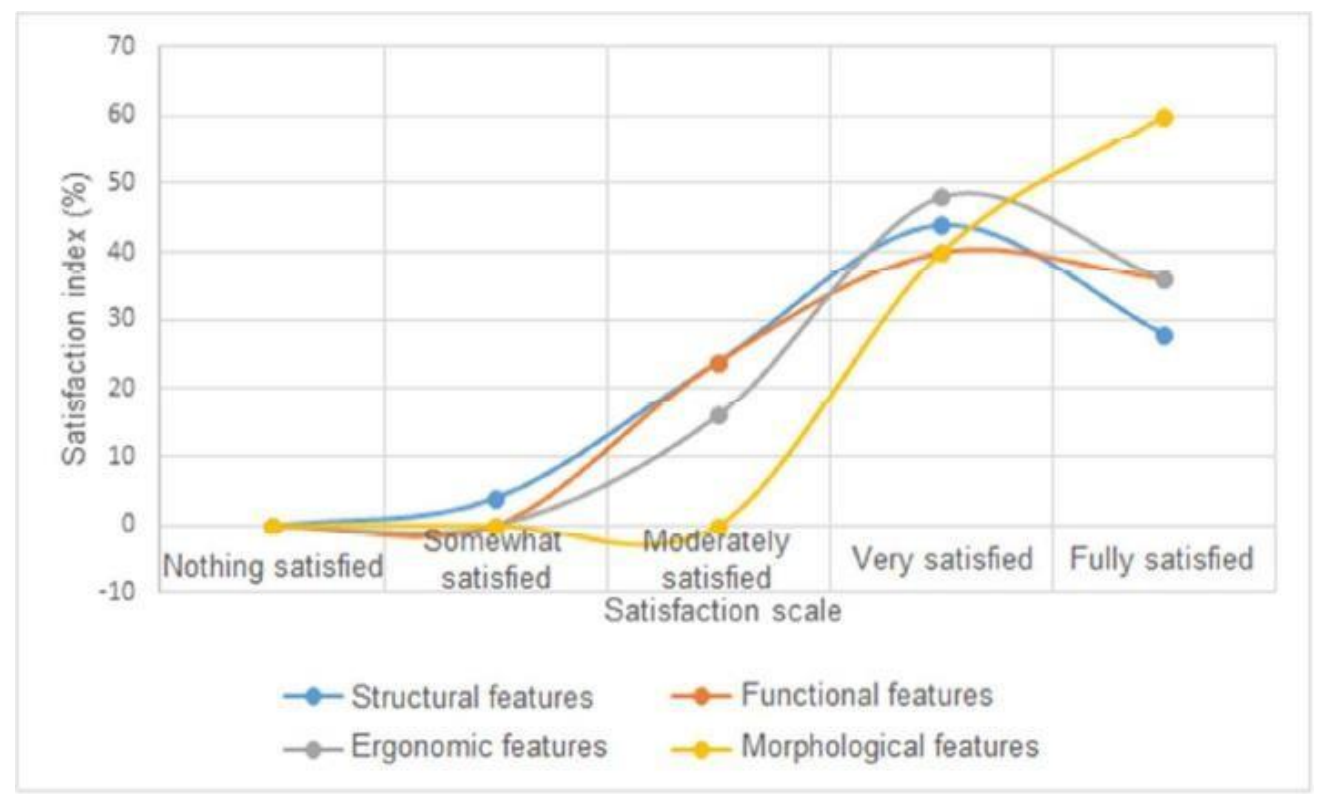

SOURCE: Authors (2018)

Figure 4 indicates that the results obtained for the determinations of the morphological character have higher quantification than the definitions of the functional, ergonomic and structural aspects (the latter has the lowest quantification). The qualification of the classes of problems of company " $\mathrm{A}$ " is similar to the qualification of company " $\mathrm{C}$ " (Figure 02), although with lower quantification and is quite distant from the results obtained by company " $\mathrm{B}$ " (Figure 03).

The result for the actions of company "A" reveal that its new product conception process is different than that at the other companies. Unlike company " $\mathrm{C}$ " which has a partial interaction between the agents involved in the new product conception process based on design, as well as company "B," which has a process considered to be fragmented for 


\section{REVISTA LATINO-AMERICANA DE INOVAÇÃO E ENGENHARIA DE PRODUÇÃO}

conducting procedures that configure the project steps, company "A" has a distinct separation between the actions or areas of action both of planning management and production management.

The steps referring to the gathering of information from clients, which serve as a basis for its approval, are tasks generated by the planning managers. Meanwhile, the submission of the project for approval by the client, as well as the development of the definitions of a technical and constructive character, are the responsibility of the production managers.

This situation reveals the vision of the company in question, given that the planning managers, in the person of the designer, conceives the project conceptually and the production managers are responsible for its materialization.

\section{CONCLUSION}

The proposed study allowed the investigation and determination of the value attributed to design in made-to-order furniture, as executed by micro and small companies in the municipality of Santa Maria-RS, based on the perception of the agents involved in the process and the characteristics of the project process that improve the chance of obtaining satisfactory results in the conception of new products based on design.

The use of a multiple case study, combined with the theoretical foundation used as a reference for the validation of the practices adopted by these companies, allowed conducting an overview of the design methods and of the action of the managers responsible for the conduct of the formal conception process and the materialization of the design. The use of the QFD method also provided a view of how these project actions qualify the design developed according to the actions of these managers.

The study indicated that design professionals are still seen as agents exclusively related to the execution of the front line processes at companies, restricting them to solutions of a conceptual character to be incorporated to the made-to-order furniture projects. This perception supports the comments made by the planning managers during the realization of the study that the designers are seen as professionals linked to functions for the "sale" of new products and almost never to decision making functions related to the productive procedure adopted and the technical resolution of the new product. 


\section{REVISTA LATINO-AMERICANA DE INOVAÇÃO E ENGENHARIA DE PRODUÇÃO}

In this way, and considering the perception of the production managers, for whom the function of design is to guarantee the morphological and functional characteristics of the new products, leaving the interpretations of a technical, constructive and structural character to the furniture makers responsible for producing the product, it was observed that various obstacles must be overcome to change the culture at micro and small furniture companies concerning the management of projects for new products based on design.

\section{FUNDING}

This work was supported in part by the Coordenação de Aperfeiçoamento de Pessoal de Nível Superior - Brazil (CAPES) [001]

\section{ACKNOWLEDGEMENTS}

We would like to thank to FAPERGS (Fundação de Amparo à pesquisa do Estado do RS) and to PPGSPI (Programa de Pós-Graduação em Sistemas e Processos Industriais Mestrado) from University of Santa Cruz do Sul - UNISC.

\section{REFERENCES}

BAXTER, M. Projeto de produto: guia prático para o desenvolvimento de novos produtos. 2. ed. São Paulo: Edgard Blücher, 2000.

BONSIEPE, G. et al. Metodologia Experimental: Desenho Industrial. Brasília: CNPq/Coordenação Editorial, 1984.

COSTA, T. Uso do QFD para mapeamento das necessidades de melhorias em uma secretaria universitária. In: XXXVII ENCONTRO NACIONAL DE ENGENHARIA DE PRODUÇAO, 2017, Joinville. Anais... Santa Catarina, 2017.

DAL PIVA, R. Processo de fabricação dos móveis sob medida. Porto Alegre: SENAI/Fiergs, 2007.

GODOY, L. P. et al. Utilização do Design como vantagem competitiva no setor moveleiro de Santa Maria/RS. Revista Produção Online, v. 12, n. 3, p. 779-805, 2012.

KO, Ya-C. et al. An Innovative Approach to Mechanical Product Designs-A Case Study on Computer Cooling Fan Design. Eurasia Journal of Mathematics, Science and Technology Education, v. 13, n. 8, p. 5855-5869, 2017.

LIN, K-Y. et al. UNISON framework of data-driven innovation for extracting user experience of product design of wearable devices. Computers \& Industrial Engineering, v. 99, p. $487-502,2016$

RAMOS, A. et al. O impacto do investimento na capacidade inovadora da empresa. Revista de Administração e Inovação, v. 12, n. 1, p. 303-325, 2015.

SCALVENZI, L. et al. QFD aplicado ao desenvolvimento de software: priorização de requisitos do cliente em uma matriz de funções. Exacta, v. 14, n. 4, 2016. 


\section{REVISTA LATINO-AMERICANA DE INOVAÇÃO E ENGENHARIA DE PRODUÇÃO}

TYAGI, S. et al. Value stream mapping to reduce the lead-time of a product development process. International Journal of Production Economics, v. 160, p. 202-212, 2015.

YIN, R. K. Estudo de Caso: planejamento e métodos. 3. ed. Porto Alegre: Bookman, 2005. 